\title{
Multi-PARTY DisPuTES: EQUITIES BETWEEN CONCURRENT TORTFEASORS
}

\author{
ELIZABETH ADJIN-TETTEY*
}

\begin{abstract}
A several concurrent tortfeasor that satisfies a plaintiff's entire damage under liability in solidum will pay more than their fair share of the plaintiff's loss. Apportionment legislation attempts to remedy this injustice through contribution and indemnity from other concurrent tortfeasors. However, the unsatisfactory wording of apportionment statutes offers no clear direction on who is entitled to contribution and against whom such a claim can be made. In practice, this can result in unfairness to the paying tortfeasor. This article explores some of the issues arising from joint liability of concurrent tortfeasors and proposes three main areas of reform to ensure fairness between concurrent tortfeasors liable for the same damage.
\end{abstract}

\section{TABLE OF CONTENTS}

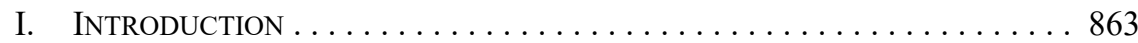

II. DISTINGUISHING CONCURRENT OR INDEPENDENT TORTFEASORS $\ldots \ldots 865$

III. PROBLEMS WITH JOINT LIABILITY OF CONCURRENT TORTFEASORS:

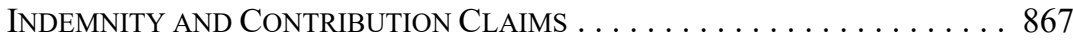

A. THE NEED FOR EQUitable CONTRIBUtion

AMONG TORTFEASORS $\ldots \ldots \ldots \ldots \ldots \ldots \ldots \ldots \ldots . \ldots \ldots$

B. Proportionate Share Settlement with

SOME TORTFEASORS ....................... 870

C. APPROPRIATENESS OF THIRD PARTY

PROCEEDINGS FOR DECLARATORY RELIEF . . . . . . . . . . . . 873

IV. DETERMINING LiABILITY AND DAMAGeS

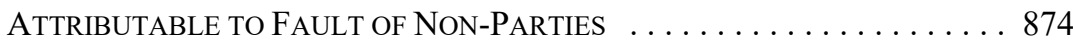

V. CONCLUSION ................................. 878

\section{INTRODUCTION}

Often, a plaintiff's injuries may be traced to the wrongful conduct of more than one person or multiple causes. The different causal factors may culminate in a single indivisible injury, giving rise to joint liability or liability in solidum. Where the multiple causes result in distinct injuries the tortfeasors are severally liable, with each defendant responsible for the damage attributable to their wrongdoing. ${ }^{1}$ Characterizing injuries as divisible or indivisible has significant implications for parties. Plaintiffs who suffer distinct injuries caused by multiple wrongdoers may risk not having their losses satisfied, either partially or wholly, where one or more tortfeasors is unknown or judgment-proof. Plaintiffs who suffer indivisible damage caused by multiple tortfeasors, however, are likely to be fully compensated even if some tortfeasors are unknown or insolvent. Concurrent tortfeasors liable for the same damage are jointly liable. A plaintiff is entitled to seek compensation for his or her entire damage from

Professor and Associate Dean, Administration and Research, Faculty of Law, University of Victoria. See Glanville L Williams, Joint Torts and Contributory Negligence: A Study of Concurrent Fault in Great Britain, Ireland and the Common-Law Dominions (London, UK: Stevens \& Sons, 1951); Lawson $v$ Viersen, 2012 ONCA 25, 346 DLR (4th) 518. 
any concurrent tortfeasor(s) whose fault caused or contributed to the loss in question. In Bradley v. Groves, the British Columbia Court of Appeal wrote:

There can be no question that Athey requires joint and several liability for indivisible injuries. Once a trial judge has concluded as a fact that an injury is indivisible, then the tortfeasors are jointly liable to the plaintiff. They can still seek apportionment (contribution and indemnity) from each other, but absent contributory negligence, the plaintiff can claim the entire amount from any of them. ${ }^{2}$

In theory, multiple known and solvent tortfeasors responsible for indivisible injuries should not be worse off due to joint liability because their liability is also several and limited to the extent of their fault. While each defendant is liable to the plaintiff for his or her entire loss, between the wrongdoers, each defendant's liability is limited to a proportion based on their degree of blameworthiness and the extent to which that conduct departed from the standard of care. Where it is impossible to determine the different degrees of fault, their liability will be apportioned equally. ${ }^{3}$

A several concurrent tortfeasor that satisfies a plaintiff's entire damage under liability in solidum will pay more than their fair share of the plaintiff's loss. Apportionment legislation attempts to remedy this injustice through contribution and indemnity from other concurrent tortfeasors. ${ }^{4}$ It tempers the harshness of the common law liability in solidum, which allowed recovery from a single joint tortfeasor and prohibited contribution from their co-tortfeasors. However, in solving this problem, the unsatisfactory wording of apportionment statutes has given rise to new difficulties. ${ }^{5}$ Apportionment legislation simply entitles tortfeasors who satisfy a plaintiff's loss beyond their proportionate share to resolve the imbalance without

22010 BCCA 361, 326 DLR (4th) 732 at para 32 [Bradley] leave to appeal to SCC refused, 33886 (14 April 2011). In British Columbia, there is no joint and several liability where the plaintiff is found to be contributorily negligent for their own losses. In such cases, the defendants are severally and not jointly liable; each defendant is liable for their proportionate share of the plaintiff's loss. There is, therefore, no guarantee a contributorily negligent plaintiff will recover their entire losses attributable to the fault of multiple defendants: see e.g. Negligence Act, RSBC 1996, c 333, ss 1, 2(c) [BC Negligence Act]; Leischner $v$ West Kootenay Power \& Light Co Ltd (1986), 24 DLR (4th) 641 (BCCA); Aberdeen $v$ Langley (Township) et al, 2007 BCSC 993, 440 WAC 116 at para 57, rev'd in part, 2008 BCCA 420, 84 BCLR (4th) 220 [Aberdeen]. In other Canadian common law jurisdictions where the plaintiff suffers damage attributable to their own fault and the fault of multiple defendants, the plaintiff is entitled to joint and several judgment for the combined damage due to the fault of the multiple tortfeasors: see Ingles $v$ Tutkaluk Construction Ltd, 2000 SCC 12, [2000] 1 SCR 298 at 327-38; Campbell's Estate v Calgary Power Ltd (1988), [1989] 1 WWR 36; Lewis N Klar, Tort Law, 5th ed (Toronto, Ont: Carswell, 2012) at $546-48$

3 See BC Negligence Act, ibid, ss 1-2; Contributory Negligence Act, RSA 2000, c C-27, ss 1, 2 [Alberta Contributory Negligence Act]; Negligence Act, RSO 1990, c N.1, ss 1, 4 [Ontario Negligence Act]; The Contributory Negligence Act, RSS 1978, c C-31, ss 2(1), 3(1) [Saskatchewan Contributory Negligence Act]; Contributory Negligence Act, RSNS 1989, c 95, ss 3-4; FFS HK Ltd v PT 25 (Ship), 2010 BCSC 1675,2010 BCSC 1675 (CanLII) at paras 170-74 [PT 25]; Rizzi v Mavros et al, 2008 ONCA 172, 236 OAC 4, leave to appeal to SCC refused, 32615 (25 September 2008); Atkinson (Guardian ad litem of) $v$ Gypsea Rose (Ship), 2014 BCSC 1017, 2014 BCSC 1017 (CanLII); Aberdeen, ibid; Alberta Wheat Pool v Northwest Pile Driving Ltd, 2000 BCCA 505, 80 BCLR (3d) 153; Heller v Martens, 2002 ABCA 122, 213 DLR (4th) 124; Drady v Canada (Minister of Health), 2007 CanLII 27970 (Ont Sup Ct J) [Drady], aff'd 2008 ONCA 659, 300 DLR (4th) 443, leave to appeal to SCC refused, 32910 (23 April 2009); Braun v Peszko, 2015 SKQB 64, [2015] 10 WWR 109 [Braun]; Klar, Tort Law, ibid at 543-44. See BC Negligence Act, ibid, s 4; Tort-feasors Act, RSA 2000, c T-5, s 3 [Alberta Tort-feasors Act]; Saskatchewan Contributory Negligence Act, ibid, s 3(1); Ontario Negligence Act, ibid, ss 1-2; The Tortfeasors and Contributory Negligence Act, RSM 1987, c T90, s 2 [Manitoba Tortfeasors Act]; Tortfeasors Act, RSNS 1989, c 471, ss 3(c), 4 [Nova Scotia Tortfeasors Act]; Drady, ibid at para 64; Bradley, supra note 2 at para 36.

$5 \quad$ See Merryweather v Nixan (1799), 8 TR 186 (KB (Eng)) [Merryweather]; Lewis N Klar, "Contribution Between Tortfeasors" (1975) 13:2 Alta L Rev 359 at 359-60. 
offering clear directions on who is entitled to contribution and against whom such a claim can be made. ${ }^{6}$ In practice, this can be an empty right, resulting in unfairness to the paying tortfeasor. This can arise when some concurrent tortfeasors are judgment-proof or remain at large. ${ }^{7}$ Deficiencies in the injured party's action that bar indemnity and contribution claims against concurrent tortfeasors may include: failure to give timely notice and expiration of the limitation period for the original action; when the plaintiff partially settles, releasing a concurrent tortfeasor; and when contractual exclusion or limitation of liability clauses limit a concurrent tortfeasor's liability to an amount less than their proportionate share of the plaintiff's loss.

This article explores some of the issues arising from joint liability of concurrent tortfeasors. It canvasses situations where tortfeasors are considered concurrent and implications of joint liability. The article examines some of the problems created by apportionment legislation aimed at addressing the harshness of the common law position that prohibited contribution among tortfeasors, issues of fairness among concurrent tortfeasors, the effect of partial settlement with some tortfeasors, the appropriateness of settling tortfeasors being part of the action by the injured party, and attribution of fault and apportionment of liability to non-parties in the injured party's action against non-settling defendants.

\section{DISTINGUISHING CONCURRENT OR INDEPENDENT TORTFEASORS}

How courts characterize multiple wrongdoers and the consequences of finding joint or several liability is a useful starting point. Concurrent tortfeasors may be joint or several. Parties are considered to be joint concurrent tortfeasors where the injury results from the concerted action of two or more persons acting together towards a common goal, where a tort was committed by one or more persons acting on behalf of another, or where one person subsequently ratifies and adopts a tort committed for their benefit. Joint tortfeasors need not have directly participated in the commission of a tort. Courts have identified five situations where a party can be indirectly responsible for another's wrong: (1) where they have a common interest in the commission of the wrong; (2) where the tort was committed by one in pursuance of a common enterprise with the other; ${ }^{8}(3)$ where there is a relationship of vicarious liability; (4) where parties have agreed to commit a tortious act and one of them carries out that plan; and (5) where the conduct of one was in breach of a joint duty. Persons who aid or abet the commission of a wrong are joint tortfeasors with those who actually

6 See Annotation by Lewis N Klar, 1977 CarswellNS 43, to Mackenzie $v$ Vance (1977), 74 DLR (3d) 383 (NSSC (AD)), cited in Investors Group Trust Co v Gordon (1998), 169 DLR (4th) 462 at para 15 (Man CA); Klar, "Contribution Between Tortfeasors," ibid at 360.

7 There could also be instances of so many concurrent tortfeasors that the right to seek contribution from individual tortfeasors would not be worth pursuing. The defendant unlucky enough to satisfy the full judgment would be left without an effective remedy.

See Brooke v Bool, [1928] 2 KB 578 cited in Gramak Ltd al v O’Connor (1973), 41 DLR (3d) 14 at 18-19 (Ont CA). See also Dempsey v Dempsey et al (1999), 224 NBR (2d) 224 (QB), where the plaintiff, while assisting a couple to construct a shed, was injured when he fell from scaffolding built by the male defendant. The male defendant's failure to design and construct a safe structure breached the standard of care. His spouse was found vicariously liable for the tort of her agent. 
execute the plan. ${ }^{9}$ Joint tortfeasors are liable for the same wrong. An action can be maintained against any one of them based on the same facts.

For parties in these situations to be concurrent tortfeasors the common goal or enterprise must itself be unlawful. ${ }^{10}$ For example, courts have found a group of motorcyclists to be joint tortfeasors for the wrong caused by one of them because they were engaged in an unlawful street race together. ${ }^{11}$ Similarly, where a group of people break into a building with the goal of committing a crime and one of them starts a fire, they are all joint tortfeasors for the resulting damage. ${ }^{12}$ Where one person commits a tort in furtherance of an otherwise lawful course of action, the resulting tort will not be imputed to those who participated in or planned that enterprise as they are not joint tortfeasors with the defendant. ${ }^{13}$

For several concurrent tortfeasors, the wrongful conduct of two or more persons acting independently runs together to produce an indivisible injury. Unlike joint concurrent tortfeasors who concur both causally and mentally, several tortfeasors only concur in causation. Each defendant is responsible for separate and independent acts that coincidentally combine to produce a single, indivisible injury. ${ }^{14}$ For example, defendants will be held to be several concurrent tortfeasors where a plaintiff is rendered totally incapable of working due to injuries sustained in two separate incidents caused by the defendants where two defendants' negligence cumulatively produces the eventual injury, ${ }^{15}$ or where an injury results from a single or successive motor vehicle accidents caused by the multiple defendants. ${ }^{16}$ A court may find that tortfeasors are several and concurrent in two situations: (1) where each tortfeasor engaged in conduct that was a necessary factor in the plaintiff's overall injuries, although that factor alone would not have been sufficient to cause the plaintiff's injury; and (2) where each tortfeasor's conduct is sufficient to cause the plaintiff's

See The Koursk, [1924] P 140 (CA); Mahesan v Malaysia Government Officers' Co-operative Housing Society Ltd (1977), [1979] AC 374 (PC); Fish \& Fish Ltd v Sea Shepherd UK, [2015] UKSC 10, [2015] AC 1229; Newcastle (Town) v Mattatall, Porter and Harris et al (1988), 87 NBR (2d) 238 (CA) [Newcastle]; Martin v Martin et al (1996), 176 NBR (2d) 178 (CA); Raywalt Construction Co v Bencic, 2005 ABQB 989, [2006] 8 WWR 440; Botiuk v Toronto Free Press Publications Ltd, [1995] 3 SCR 3; W Page Keeton et al, Prosser and Keeton on the Law of Torts, 5th ed (St Paul, Minn: West, 1984) at 323; GHL Fridman, The Law of Torts in Canada, 2nd ed (Toronto: Carswell, 2002) at 888-91. Express agreement between defendants is not required: see Drady, supra note 3 at para 63 .

10 See Insurance Corp of British Columbia v Vancouver (City), 2000 BCCA 12, 182 DLR (4th) 366 at paras 11-17. The agreement to engage in unlawful conduct is not applicable in cases of vicarious liability. In such cases, although employers are considered joint tortfeasors with their employees for whose torts they are vicariously liable, there will be no prior agreement or common interest in furtherance of a wrongful conduct, yet liability is imposed on policy grounds. For a discussion of the policy rationale for vicarious liability, see Bazley $v$ Curry, [1999] 2 SCR 534.

11 See Chow v Chan, 2007 BCSC 392, 46 CCLT (3d) 249; McDonald v Dalgleish, [1973] 2 OR 826 (H Ct J).

12 See Lambton Cartage \& Warehousing Ltd v Barraclough (Litigation Guardian of)(1998), 10 CCLI (3d) 107 (Ont Ct J (Gen Div)); Newcastle, supra note 9.

13 See Cook $v$ Lewis, [1951] SCR 830 at 841; Keough $v$ Henderson Highway Branch No 215 of the Royal Canadian Legion (1978), 91 DLR (3d) 507 (Man CA); Horvath v Thring, 2005 BCCA 127, 39 BCLR (4th) 124; David Cheifetz, Apportionment of Fault in Tort (Aurora, Ont: Canada Law Book, 1981) at 6.

14 See PT 25, supra note 3. The ship and bargemen were jointly liable in negligence for the damage resulting from an oil spill at the harbour. The ship's crew was negligent in having left open one of the ship's valves and for failing to monitor the ship during fueling; the bargemen were negligent in pumping the fuel at a higher rate than was agreed upon and for failing to monitor the amount of oil going into the ship, which resulted in one of the tanks overflowing.

15 See The Koursk, supra note 9; Drinkwater v Kimber, [1952] 2 QB 281; B (BP) v B (MM), 2009 BCCA 365 , [2010] 3 WWR 628 at paras 69-70 [B(BP)], leave to appeal to SCC refused, 33503 (13 May 2010). See Brown Estate v Britsky, 2010 ABQB 445, 2010 ABQB 445 (CanLII), aff'd Golf Western Ltd et al $v$ Britsky et al, 2011 ABCA 274, 530 WAC 340. 
injury. In either situation, each tortfeasor's conduct caused or contributed to the plaintiff's injuries and is therefore fully liable for those injuries. ${ }^{17}$

Concurrent tortfeasors, whether joint or several, whose conduct results in an indivisible injury are jointly and severally liable. ${ }^{18}$ This entitles plaintiffs to sue one or more defendants for their entire losses. ${ }^{19}$ A plaintiff will often sue the defendant(s) with deep pockets. The tortfeasor who satisfies the plaintiff's loss beyond their proportionate liability is entitled to seek contribution or indemnity from co-tortfeasors for their share of liability for the plaintiff's losses under apportionment legislation. ${ }^{20}$ Unaddressed, this benefit for the concurrent tortfeasors who have not paid would be an unjust enrichment. ${ }^{21}$

\section{Problems With Joint Liability of Concurrent TORTFEASORS: INDEMNITY AND CONTRIBUTION CLAIMS}

Contribution is a concept which is deeply rooted in our legal history. It provides a mechanism for the achievement of the fundamental policy which Aristotle termed corrective justice. ${ }^{22}$

... contribution is a simple concept but it has not been simple in implementation. ${ }^{23}$

See Williams, supra note 1 at 1, 17; Athey $v$ Leonati, [1996] 3 SCR 458 at paras 13, 17-20 [Athey]; B (PB), supra note 15; EDG v Hammer, 2003 SCC 52, [2003] 2 SCR 459.

See BC Negligence Act, supra note 2, s 4; Alberta Contributory Negligence Act, supra note 3, s 2(2); Manitoba Tortfeasors Act, supra note 4, s 5; Ontario Negligence Act, supra note 3, s 1; Contributory Negligence Act, RSNB 1973, c C-19, s 2(2) [NB Contributory Negligence Act]. At common law, only joint tortfeasors were subject to joint and several liability. Although independent concurrent tortfeasors are liable for the same damage, their liability remained several: see Williams, ibid at 4-5.

19 It appears that joint and several liability is applicable only in relation to the plaintiff's compensatory damages, including aggravated damages, and does not include liability for punitive damages, which is several: see Blackwater v Plint, 2005 SCC 58, [2005] 3 SCR 3; Hill v Church of Scientology of Toronto, [1995] 2 SCR 1130; A (TWN) v Clarke (2003), 235 DLR (4th) 13 (BCCA); Ottawa Community Housing Corp v Foustanellas, 2015 ONCA 276, 125 OR (3d) 539 at para 79 (punitive damages must be assessed only against party guilty of misconduct deserving of punishment).

See Athey, supra note 17 at para 22. Apportionment legislation abrogates the common law rule established in Merryweather, supra note 5, that precluded a tortfeasor from seeking contribution from other tortfeasors. The common law bar to contribution has now been abrogated by legislation that permits defendants to seek contribution and indemnity among themselves. The defendant who satisfies the judgment may seek contribution or indemnification from the other defendants liable for the plaintiff's loss and the court must determine their respective degrees of fault for the plaintiff's injury: see e.g. Ontario Negligence Act, supra note 3, s 1; Manitoba Tortfeasors Act, supra note 4, s 2(1)(a); Nova Scotia Tortfeasors Act, supra note 4, s 3(c); BC Negligence Act, supra note 2, s 4(2)(b). As already noted, in British Columbia, there is no joint and several liability where the plaintiff is partly at fault for their injury: see Williams, supra note 1.

See Placzek v Green, 2009 ONCA 83, 307 DLR (4th) 441 at paras 34-38; Strata Plan LMS 1751 v Fairchild Projects No 12 Ltd; Strata Plan LMS 1751 v Scott Management Ltd, 2010 BCCA 192, 318 DLR (4th) 567 at paras 19-22. It has been argued that the restitutionary justification for contribution or indemnity claims loses its force where the payment has not benefitted the party against whom contribution or indemnity is sought, for example because the injured party could not have sued them. See Andrew Kull, "The Source of Liability in Indemnity and Contribution" (2003) 36:2 Loy LA L Rev 927.

Ernest J Weinrib, “Contribution in a Contractual Setting” (1976) 54:2 Can Bar Rev 338 at 349-50 [footnotes omitted].

Peter B Kutner, "Contribution Among Tortfeasors: Liability Issues in Contribution Law” (1985) 63:1 Can Bar Rev 1 at 4. 
Liability in solidum has a strong policy justification to ensure plaintiffs are fully compensated for their losses. ${ }^{24}$ Apportionment legislation seeks to ensure fairness among tortfeasors through contribution and indemnity. However, the statutory right of contribution and indemnity may not always result in equity among tortfeasors. A tortfeasor may be unable to seek contribution from a co-tortfeasor due to the latter's impecuniosity, immunity from suit, or other procedural bars such as the injured party's failure to give statutorily required notice. This seems particularly problematic where independent concurrent tortfeasors are liable for the wrongdoing of others, even where they had no knowledge of or connection to each other except that their independent actions combined to produce the plaintiff's loss.

Although each concurrent tortfeasor is liable for the plaintiff's entire loss, courts will apportion liability among joint tortfeasors to allow contribution claims. This apportionment gives the maximum amount that can be sought from each co-tortfeasor. The rule works well when all defendants are known and solvent. In practice, however, it can lead to unfairness between concurrent tortfeasors left with the burden of seeking contribution, and the possibility that an unsuccessful claim will leave them shouldering the cost of the injured party's entire loss.

While courts and legislatures are comfortable with this risk falling on a wrongdoer rather than a victim, there are four situations where some provinces' contribution and indemnity regimes still produce inequitable outcomes for concurrent tortfeasors: (1) where some concurrent tortfeasors are impecunious; (2) where a release exists rather than a covenant not to sue for concurrent tortfeasors; (3) where the plaintiff settles with some but not all concurrent tortfeasors; and (4) where not all possible tortfeasors may be before the court when issues of liability are determined. As well, should an alleged tortfeasor who did not participate in the main action, and therefore did not have the opportunity to respond to allegations of wrongdoing, be liable to the tortfeasor who satisfies a judgment in the plaintiff's favour?

\section{A. The NeEd For EQUitable CONTRIBUtion AMONG TORTFEASORS}

The liability between co-tortfeasors is several, limited to each tortfeasor's proportionate share of the plaintiff's damage. ${ }^{25}$ Even where some co-tortfeasors are unknown or insolvent, the paying tortfeasor cannot seek contribution to amortize the missing share between the known and solvent tortfeasors. Since a co-tortfeasor cannot resist the injured party's claim for full compensation, they will always bear the risks of non-recovery. While this protects the interests of plaintiffs in obtaining full recovery for their losses from any concurrent tortfeasor, it does not eliminate potential unfairness to the paying tortfeasor.

This problem stems from the wording of apportionment legislation limiting a tortfeasor's contribution to the degree of their fault. To avoid the unfairness, the legislation in Saskatchewan provides specifically for equitable contribution towards uncollectible amounts 
by dividing this share up among the solvent co-tortfeasors. ${ }^{26}$ Equitable contribution has also been legislated in some cases of pure economic losses involving joint tortfeasors. ${ }^{27}$ Legislation in Alberta, Manitoba, and Nova Scotia empowers courts to set the amount recoverable in contribution claims as the court deems just and equitable in the circumstances, considering each party's degree of blameworthiness. ${ }^{28}$ This may provide an opening for courts to consider factors other than a tortfeasor's degree of fault including fairness between tortfeasors, and may be the basis for pro rata distribution of an impecunious tortfeasor's share of damages among solvent tortfeasors in contribution claims. However, courts have refused to permit pro rata contribution of an impecunious tortfeasor's liability for the loss absent express legislative authority. ${ }^{29}$ Arguably, this provision should not limit the amount recoverable in a contribution claim solely based on a co-tortfeasor's proportionate fault. Alternatively, the legislation should specifically provide for pro rata contribution of the uncollectible amount as is the case in Saskatchewan. Courts should be empowered to set the contribution amount, taking account of any uncollectible amount to ensure equitable contribution between known and solvent tortfeasors. The legislation in Alberta, Manitoba, and Nova Scotia also empowers courts to exempt any person from making a contribution or to hold that the contribution recoverable from any person constitutes complete indemnity. ${ }^{30}$ While equitable contribution can hold a tortfeasor liable for more than their proportionate share of the plaintiff's losses, it is consistent with the principle of joint liability. Since they could have been held wholly liable for the plaintiff's losses, a system of equitable contribution is a fair, common sense approach, balancing the interests of all known and solvent defendants. ${ }^{31}$

Saskatchewan Contributory Negligence Act, supra note 3 (for damages occurring after 1 January 2005); Braun, supra note 3 at para 236. See also Uniform Law Conference of Canada, Uniform Contributory Fault Act, s 9, online: <www.ulcc.ca/images/stories/Uniform_Acts_EN/Contribu_En.pdf>.

27 See Canada Business Corporations Act, RSC 1985, c C-44, ss 2337.1-237.9 (applies proportionate liability in respect of financial losses caused by negligently prepared information about a corporation required under the Act and equitable contribution in respect of damages that remain unpaid because the tortfeasors are insolvent or cannot be found). See also the Civil Liability Act 2002 (NSW), ss 34-39 (grants proportionate liability for economic loss or property damage).

28 See Alberta Tort-feasors Act, supra note 4, s 3(2); Manitoba Tortfeasors Act, supra note 4, s 2(2); Nova Scotia Tortfeasors Act, supra note 4, s 4(1). See also the Civil Liability (Contribution) Act 1978 (UK), c 47, s 2(1). It must be noted that many US jurisdictions have abolished joint and several liability except in cases of joint concurrent tortfeasors and concurrent tortfeasors causing environmental harm, leaving proportionate liability as the dominant position. As such, these jurisdictions have, to a large extent, also avoided problems relating to contributions among concurrent tortfeasors. Some jurisdictions that have abolished joint and several liability beyond the two areas may allow reallocation of uncollectible judgment debt among liable and presumably solvent concurrent tortfeasors, including released persons, and contributorily negligent plaintiffs upon the plaintiff satisfying the court that judgment against some multiple defendants cannot be satisfied: see Uniform Apportionment of Tort Responsibility Act, Preface at 4-5, §5 (2002), online: <www.uniformlaws.org/shared/docs/apportionment_of_tort_responsibility/ tort final jan04.pdf $>$ [Tort Responsibility Act].

29 See Steele et al v Burgos et al, 2010 ABQB 327, 535 AR 20 at paras 170-73. See also 376599 Alberta Inc $v$ Tanshaw Products Inc et al, $2005 \mathrm{ABQB} 300,379 \mathrm{AR} 1$ ("there is no authority for the proposition that the court, upon giving judgment, may order that an insolvent defendant's share of the damages be distributed pro rata among the other defendants" at para 218).

30 Tort-feasors Act, supra note 4, s 3(3); Nova Scotia Tortfeasors Act, supra note 4, s 4(1); Manitoba Tortfeasors Act, supra note 4, s 2(2); Civil Liability (Contribution) Act, supra note 28, s 2(2).

31 See Barbara McDonald, “Concurrent Wrongdoers" in Carolyn Sappideen \& Prue Vines, eds, Fleming's The Law of Torts (Sydney, Austl: Lawbook, 2011) 301 at 312. 


\section{B. Proportionate Share Settlement WITH SOME TORTFEASORS}

A tortfeasor may want to settle with the plaintiff for a myriad of reasons including to simplify trials, minimize costs, resolve claims in a timely manner, avoid the possibility of an unfavourable outcome in court, increase the plaintiff's access to compensation, give the settling party closure, or avoid negative publicity. In fact, courts have upheld "the overriding public interest in encouraging the pre-trial settlement" as essential for the effective administration of justice. ${ }^{32}$ In Sable Offshore Energy Inc v. Ameron International Corp. Justice Abella reiterated support for encouraging settlements to minimize resorting to litigation, stating: "[t]he justice system is on a constant quest for ameliorative strategies that reduce litigation's stubbornly endemic delays, expense and stress." 33 The Supreme Court of Canada's desire to encourage settlement was echoed by Justice Karakatsanis in Hryniak v. Mauldin, noting that in addition to delays, the litigation process has become cost prohibitive for ordinary Canadians, no longer reflects the modern reality, and should be reconsidered. ${ }^{34}$

Where damage has been caused by the fault of several concurrent tortfeasors, some or all of them may settle with the plaintiff. The settlement may cover the plaintiff's entire loss or part of the loss attributable to the fault of the settling tortfeasor. Pursuant to the principle against double recovery, where the settlement amount was intended to compensate the plaintiff for their entire loss, no further claims can be made against any other tortfeasor, whether they were part of the settlement or not. Where the settlement amount was neither intended to be in full and final satisfaction nor fully satisfies the plaintiff's loss, ${ }^{35}$ the plaintiff is entitled to sue the non-settling tortfeasors for their proportionate share of the damage unless the settlement includes a release of those tortfeasors. ${ }^{36}$ These agreements, referred to as "Pierringer Settlement Agreements," "37 are proportionate share settlement agreements and provide ways to simplify complex multi-party litigation. They give parties that desire to settle with the plaintiff an opportunity to do so, inter alia, to avoid the risks and costs associated

$M(J) v$ Bradley (2004) 71 OR (3d) 171 at para 65 (CA) [M(J)]. See also Amoco Canada Petroleum Co $v$ Propak Systems Ltd, 2001 ABCA 110, 200 DLR (4th) 667 at paras 12-13 [Amoco], leave to appeal to SCC refused, 28708 (25 April 2002).

332013 SCC 37, [2013] 2 SCR 623 at para 1 [Sable Offshore Energy].

342014 SCC 7, [2014] 1 SCR 87 at paras 24, 27-28.

35 In Jameson $v$ Central Electricity Generating Board, [1998] UKHL 51, [2000] 1 AC 455 [Jameson], the House of Lords concluded that no further action would lie against concurrent tortfeasors where a settlement with other tortfeasors is intended to be in full satisfaction of the plaintiff's loss even if the amount of the settlement did not fully compensate the plaintiff for their losses. Jameson has been criticized as being unfair to unsuspecting plaintiffs and should not be adopted in other jurisdictions. Jameson has received a negative treatment in Chu Siu Kuk Yuen v Apple Daily Ltd, [2002] 1 HKLRD 1, 2002 WL 2801 (CFI Hong Kong), but otherwise has been well received throughout the Commonwealth: see Allison v KPMG Peat Marwick, [2000] 1 NZLR 560 (CA); Baxter v Obacelo Pty Ltd, [2001] HCA 66, 205 CLR 635 (distinguished in two cases, but overwhelmingly treated positively by Australian courts). See also Tony Weir, “ALL or Nothing?" (2004) 78:3 Tul L Rev 511 at 522.

36 The plaintiff is entitled to recover the difference between the amount recovered in the previous proceedings or settlement and their overall damages awarded in the subsequent action, if any, subject to a Pierringer Agreement that limits the liability of the non-settling defendants to the proportionate share of the damages attributable to their fault: see Ashcroft $v$ Dhaliwal, 2008 BCCA 352, 298 DLR (4th) 509 at paras 18-20, leave to appeal to SCC refused, 32889 (19 February 2009); Dixon v British Columbia (1979), 99 DLR (3d) 652 at 661-62 (BCSC), aff'd (1980), 128 DLR (3d) 389 (BCCA); Logan $v$ Canada Safeway Limited, 2006 BCSC 1733, 2006 BCSC 1733 (CanLII) at para 50; Cummings $v$ 565204 BC Ltd, 2009 BCSC 1009, [2010] 1 BCLR (5th) 351 at paras 63-69; Sable Offshore Energy, supra note 33.

37 This type of agreement derives its name from the Wisconsin case Pierringer $v$ Hoger et al, 124 NW (2d) 106 (Wis 1963). 
with litigation. As well, these agreements promote effective administration of justice and sound judicial policy. ${ }^{38}$ In Sable Offshore Energy, Justice Abella wrote:

[A] Pierringer Agreement allows one or more defendants in a multi-party proceeding to settle with the plaintiff and withdraw from the litigation, leaving the remaining defendants responsible only for the loss they actually caused. There is no joint liability with the settling defendants, but non-settling defendants may be jointly liable with each other. ${ }^{39}$

Pierringer Settlement Agreements often include a release of the settling party, precluding the plaintiff from suing the non-settling tortfeasors for damage attributable to the settling tortfeasors' wrongdoing, and protecting the settling tortfeasor from indemnity and contribution claims. ${ }^{40}$ All non-settling tortfeasors are jointly and severally liable for the combined share of the plaintiff's losses attributable to their fault excluding those due to the fault of the settling parties. ${ }^{41}$ Courts may dismiss a motion to amend the statement of claim to discontinue litigation against the settling defendants unless the terms of the proportionate share agreement unequivocally limit the plaintiff's claim against the non-settling defendants to their several liability. ${ }^{42}$ The United States Tort Responsibility Act pre-empts this situation by making it clear that the claim of a releasing party against other concurrent tortfeasors for the same damage will be reduced by the percentage of fault attributed to the released person, and no contribution can be sought from the latter. ${ }^{43}$

See Sable Offshore Energy, supra note 33 at paras 21-26; Amoco, supra note 32; Marble (Litigation Guardian of) v Saskatchewan, 2003 SKQB 282, [2004] 7 WWR 580 [Marble]; Nadeau Poultry Farm Ltd v Desjardins \& Desjardins Consultants Inc, 2014 NBQB 81, 425 NBR (2d) 1 [Nadeau Poultry Farm].

39 Sable Offshore Energy, ibid at para 6.

40 Pierringer agreements are distinguishable from Mary Carter agreements, which are another form of proportionate share agreements. Mary Carter agreements originate from Booth $v$ Mary Carter Paint Company, 202 So (2d) 8 (Fla Dist Ct App 1967). In Pierringer agreements, the plaintiff's action against the settling defendants is discontinued; the settling defendants do not participate in the plaintiff's action against the non-settling defendants, subject to a court ordering their participation as third parties in the interest of justice to the non-settling defendants. Parties have to immediately disclose the fact of a Pierringer settlement, but the amount of settlement is protected by settlement privilege subject to a competing public interest that outweighs the public interest in encouraging settlement. The settlement amount will often be disclosed after the assessment of the plaintiff's damages at trial and in assessing the amount recoverable from the non-settling defendant, if any: see Sable Offshore Energy, ibid; Bioriginal Food \& Science Corp et al v Gerspacher et al, 2012 SKQB 469, 410 Sask R 158. On the other hand, settling defendants in Mary Carter agreements remain parties to the plaintiff's lawsuit against the non-settling defendants, presumably to assist the plaintiff in establishing liability in exchange for better terms, usually for the settling defendant to pay less than the settlement amount or nothing depending on the quantum of damages recovered from the non-settling defendant. In addition to the obligation to immediately disclose the fact of the agreement to the non-settling defendants and the court, courts also have discretion to determine the extent of disclosure of the terms of the agreement in the interest of justice and fairness. These agreements alter the tenor of the litigation and can influence litigation strategies. An undisclosed Mary Carter agreement can result in double recovery and can mislead both the non-settling defendants and the court. In Aecon Buildings $v$ Stephenson Engineering Ltd, 2011 SCC 33, [2011] 2 SCR 560, the Supreme Court held that failure to immediately disclose a Mary Carter agreement was an abuse of process, resulting in a stay. See also Laudon v Roberts, 2009 ONCA 383, 308 DLR (4th) 422, leave to appeal to SCC refused 33264 (5 November 2009); Stamatopoulos v Harris, 2013 ONSC 4143, 47 MVR (6th) 277, aff'd 2014 ONSC 6313, 123 OR (3d) 234. For a discussion of the distinction between Pierringer and Mary Carter agreements, see Nadeau Poultry Farm, supra note 38; Brian Samuels, "Mary Carter and Pierringer Agreements: Characteristics, Differences, and Pitfalls" [2014] J Can College Construction Laywers 43.

$41 \quad$ See Misko v Doe (2007), 87 OR (3d) 517 (CA) [Misko]; British Columbia Ferry Corp v T \& N plc (1995), [1996] 4 WWR 161 (BCCA) [BC Ferry]; Amoco, supra note 32; M (J), supra note 32. See also Uniform Contributory Fault Act, supra note 26.

42 See Chiarella v Klymok, 2011 ABQB 814, 2011 ABQB 814 (CanLII); Sable Offshore Energy, supra note 33 .

$43 \quad$ Supra note $28, \S 8$. 
The non-settling tortfeasors cannot raise a settling party's release to bar a plaintiff's claim for the damages attributable to the non-settling tortfeasors' fault. The settlement and release are contractual arrangements between the settling parties; privity of contract prevents strangers to the contract from benefiting under $\mathrm{it}^{44}$ unless there is an express intention to benefit those persons. ${ }^{45}$ As well, non-settling tortfeasors cannot add the settling tortfeasors as third parties in the plaintiff's action against them for their proportionate share of the plaintiff's damages. This is subject to the court's discretion to allow the non-settling defendants to join the settling parties for procedural purposes (see Part III.C, below). Further, settling tortfeasors are immune from contribution and indemnity claims by non-settling defendants.

Releases under Pierringer Settlement Agreements do not guarantee that third party claims against the settling tortfeasor will be dismissed. Courts have discretion to allow a third party claim to proceed where attributing fault is still in issue and dismissing the third party action would significantly prejudice the non-settling party's defence against the plaintiff's claim. As well, a court may allow a settling tortfeasor to be joined as a third party where it is necessary to establish the degree of fault of the third party. In such cases, the purpose of the third party proceeding, and for including the settling party in the litigation is simply to grant declaratory relief and not to expose that party to any liability. ${ }^{46}$ Consistent with the public policy in favour of settlement, a request for declaratory relief will be denied where it will serve no real purpose in the litigation or could prejudice the interests of the settling parties. ${ }^{47}$

Including a settling party in the litigation to give the non-settling party procedural remedies does not expose the former to contribution and indemnity claims or further liability. However, it forces such persons to be part of the proceedings and potentially incur costs for legal representation that should have been avoided with the settlement. This undermines part

See Fraternal Order of Eagles Winnipeg Aerie No 23 v Blumes, [1994] 7 WWR 360 (Man CA); BPB $v M M B, 2006$ BCSC 1027, 2006 BCSC 1027 (Can LII) at paras 91, 93, rev'd on other grounds B (BP), supra note 15; Holthaus v Bank of Montreal (1999), 41 CPC (4th) 347 (Ont Sup Ct J), aff'd Holthaus et al v Bank of Montreal et al (2000), 131 OAC 119; Van Patter v Tillsonburg District Memorial Hospital (1999), 45 OR (3d) 223 (CA); Disera v Bernardi, 2014 ONSC 4500, 2014 ONSC 4500 (CanLII) at paras 38-42. See also Jameson, supra note 35; His Honour Judge Walton, Roger Cooper \& Simon E Wood, Charlesworth \& Percy on Negligence (London, UK: Sweet \& Maxwell, 2006) at para 2-284; Uniform Contributory Fault Act, supra note 26, s 15.

45 See Zelsman v Meridian Credit Union, 2011 ONSC 1680, 100 CCLI (4th) 210, aff'd 2012 ONCA 358 10 CCLI (5th) 229, leave to appeal to SCC refused, 34941 (6 December 2012) where a plaintiff settled her human rights complaint against her former employer with the execution of a Minutes of Settlement. That settlement was intended to resolve all the issues relating to the plaintiff's employment and clearly released the insurer from providing benefits under the group policy. The insurer was therefore an intended third party beneficiary of the release executed between plaintiff and her employer. See also Thompson v Musliyan, 2010 ONSC 5351, 89 CCLI (4th) 249 where a release executed between the plaintiff and two defendants which was not intended for the benefit of the defendants who had not responded to the plaintiff's claim at the time the release was executed and were not named therein. See also Marble, supra note 38; Fred D Cass, The Law of Releases in Canada (Aurora, Ont: Canada Law Book, 2006) at 144-47.

$46 \quad$ See BC Ferry, supra note 41; Common Ground Housing Co-Operative v Cambie Roofing Contractors Ltd, 2009 BCSC 872, [2009] 12 WWR 252 at paras 9-10, 12-13; Scott Paper Limited v First Choice Logistics Inc, 2008 BCSC 1427, 2008 BCSC 1427 (CanLII) at para 8; Rurka v JLG Industries Inc (1999), 30 CPC (4th) 34 (BCSC) at paras 33-40 [Rurka]; Marelj v Gosselin, 2001 BCSC 1491, 94 BCLR (3d) 351 at para 10.

47 See Amoco, supra note 32; Manitoba Public Insurance Corp v Cloutier et al, 2012 MBQB 185, 279 Man R (2d) 311; Abdulrahim v Air France, 2009 CanLII 72086 (Ont Sup Ct J), aff'd 2010 ONCA 403, 2010 ONCA 403 (CanLII); M (J), supra note 32; Nadeau Poultry Farm, supra note 38; College of New Caledonia v Kraft Construction Co, 2007 BCSC 1408, 63 CLR (3d) 197 [College of New Caledonia], leave to appeal to BCCA refused, 2011 BCCA 172, 515 WAC 48. 
of the rationale for pre-trial settlements, including minimizing cost, timely resolution of claims, and the general public interest in promoting settlement. In College of New Caledonia, the British Columbia Supreme Court emphasized the extraordinary nature of allowing third party proceedings for purely declaratory relief, noting that courts must exercise their discretion to grant such relief with extreme caution. ${ }^{48}$ In Amoco, Justice Fruman notes that courts must approach the determinative factor for keeping settling defendants in the proceedings - potential prejudice to the non-settling party — with caution. By choosing to settle with some defendants, the plaintiff runs the risk of not having all potential tortfeasors in court and possibly not being able to prove their case at trial. In these situations, Amoco held that potential prejudice to the defendant is balanced against the risk to the plaintiff not proving their case at trial. This makes the analysis uncertain for parties and unclear for the courts.

\section{APPROpriateness OF Third PARTy ProceEdings FOR DeClaRATORY RELIEF}

The current position is to encourage settlement as a matter of public policy and to promote judicial economy. Courts will give a high degree of deference to proportionate share agreements and the release of the settling parties. What constitutes potential prejudice to nonsettling defendants to warrant keeping settling defendants in the litigation for procedural reasons must be restrictively construed. ${ }^{49}$ According to Justice Fruman, determinations of potential prejudice to the non-settling defendant with the absence of the settling party will depend on the length of time that the claim has been going on and the extent of opportunities that the non-settling defendant might have had for pre-trial disclosure. Generally, the longer the action has been going on and the greater pre-trial disclosure that the non-settling defendant has been privy to, the less likely it is that a party will be prejudiced by the absence of the settling defendant from the action. ${ }^{50}$ However, Justice Fruman also notes that this is an unsatisfactory test because it is inherently uncertain and appears to favour settlement agreements late in the proceedings, which is contrary to the public policy of encouraging settlement sooner rather than later. ${ }^{51}$ Justice Fruman notes that potential prejudice may be avoided or at least minimized with broader cooperation from the settling party, such as generous disclosure by the settling party including disclosure of the terms of the settlement agreement to the court. ${ }^{52}$ In Murphy Canada Exploration Co. v. Novagas Canada Ltd. et al., the Alberta Court of Appeal reiterated support for attempting to mitigate potential prejudice to the non-settling parties and keeping the settling party in the proceedings only as a last resort. $^{53}$

Courts have generally taken the position that the discretion to grant declaratory relief for purely procedural purposes will be exercised sparingly and certainly not to allow defendants

Ibid at para 90 .

Amoco, supra note 32.

Ibid at para 30 .

Ibid at paras $31-33$.

Ibid at paras 29-41.

2009 ABQB 455, 481 AR 134 [Murphy Canada Exploration]. Here the Court found that the non-settling defendant risked significant prejudice with the absence of the settling party from the proceedings but concluded that this could be mitigated by allowing the non-settling defendant to effectively discover the settling defendant. 
to circumvent settlement agreements insulating non-parties from further liability. ${ }^{54}$ Such an approach assures settling parties they will rarely be drawn into litigation after concluding proportionate share agreements and is consistent with the public policy in favour of encouraging settlements.

Third party proceedings for declaratory relief may not be sustainable where such a claim is specifically precluded by statute or where that party is immune from liability by operation of law. ${ }^{55}$ Courts distinguish between parties who would have been liable to the plaintiff at the time of damage but have subsequently acquired immunity from suit and those who could never have been liable. While courts may grant declaratory relief for procedural advantage against parties in the former category, they will not grant the remedy against those in the latter. Immunity precludes all actions against such parties. For instance, in Imperial Tobacco $\mathrm{SC}$, by upholding the striking of the third party claim against Canada for a declaratory relief, the British Columbia Supreme Court emphasized that not only was Canada immune from third party claim, but in any event, Canada's non-involvement in the litigation would not be detrimental in determining the defendants' liability. ${ }^{56}$

In Rurka, the British Columbia Supreme Court adopted a contrary view, holding that absent an explicit provision to the contrary, immunity from civil liability for damage or contribution for losses caused by an employer or employee under the workers' compensation regime did not preclude third party proceedings for declaratory relief on the basis of avoiding prejudice to the defendant. ${ }^{57}$ Given the importance of permitting third party proceedings for declaratory relief where it is necessary to avoid prejudice to the defendant, an absolute position of precluding such claims in respect of immune parties may be extreme. This is a discretionary remedy and courts will likely exercise their discretion to permit such proceedings in exceptional circumstances where the defendant risks substantial prejudice unless the court allows the third party claim, albeit for declaratory relief. ${ }^{58}$

\section{DETERMINING LIABILITY AND DAMAGES AtTributable to Fault of Non-PARTies}

The issue has been raised whether a court can apportion fault and hence damages against non-parties. Such a determination will not necessarily expose the tortfeasor sued to damages attributable to the fault of the non-party and hence there can be no claim for contribution and indemnity. Rather, it is merely intended to identify the portion of the plaintiff's damages attributable to the fault of the non-parties, which must be severed before imposing joint and

See BC Ferry, supra note 41 at para 29; Wright (Next Friend of) v VIA Rail Canada Inc, $2000 \mathrm{ABQB}$ 8 , [2000] 4 WWR 232 at paras 45-47.

55 See Pearse v Canpar Transport Ltd, 2001 BCSC 594, 88 BCLR (3d) 312 [Pearse]; British Columbia v Imperial Tobacco Canada Ltd, 2008 BCSC 419, 292 DLR (4th) 353 at paras 86-93 [Imperial Tobacco SC] rev'd in part 2009 BCCA 540, 313 DLR (4th) 651, aff'd $R$ v Imperial Tobacco Canada Ltd, 2011 SCC 42, [2011] 3 SCR 45 [Imperial Tobacco SCC].

56 Imperial Tobacco SC, ibid. The appellants had full and complete knowledge of Canada's role in the events that formed the basis of the claim against the tobacco manufacturers. As well, Canada had agreed to submit to the Rules of Court, which would enable the court to make the necessary determinations regarding the defendants' liability.

$57 \quad$ Supra note 46. See also Pearse, supra note 55.

58 Imperial Tobacco SC, supra note 55 at paras 89-95, aff'd Imperial Tobacco SCC, supra note 55 at paras $149-50$ 
several liability on the defendants for the combined damage attributable to the fault of the tortfeasors sued.

A further question arises: whether a concurrent tortfeasor who satisfies the plaintiff's damages can seek contribution or indemnity from an alleged tortfeasor not named as a party in the main action initiated by the plaintiff, as is discussed below. The concern is that findings of liability and apportionment of damages to a person not a party to the original action is problematic because that person would not have had the opportunity to defend her or himself in the original action. In Martin et al. v. Listowel Memorial Hospital, ${ }^{59}$ the Ontario Court of Appeal noted that a court has no jurisdiction under section 1 of the Ontario Negligence Act to apportion fault and hence damages to a non-party. ${ }^{60}$ According to Martin, a finding of joint and several liability for the plaintiff's losses is applicable only in respect of parties before the court and does not include absent tortfeasors. ${ }^{61}$ Liability for the plaintiff's losses will have to be apportioned among the tortfeasors before the court. ${ }^{62}$ The rationale for this position is partly the difficulty and unfairness in determining a tortfeasor's liability and extent of fault in absentia, with no opportunity to defend the action against them and present evidence that may point to their non-culpability or extent of fault. ${ }^{63}$ A plaintiff may choose not to sue an alleged tortfeasor because they may be judgment proof. Defendants who satisfy the plaintiff's loss may be prejudiced by the absence of equitable contribution, which precludes the paying defendant from obtaining the portion of the non-party's damages from the other named defendants in contribution and indemnity claims. In Martin, the Ontario Court of Appeal explained the policy rationale for that position:

\footnotetext{
The effect of a finding of a degree of fault on a non-party could have significant consequences for the other defendants under this section. If the fault is apportioned only among the parties, then if there is a non-party who may also have been at fault and contributed to the damage, a larger percentage of the whole loss may be attributed to each party, so that the entire loss is divided for indemnity purposes, and no gap is left. But if a portion of the fault were attributed to a non-party, or to a party at fault but with a legal defence such as a limitation defence, the defendants who are liable to the plaintiff would be left with no one from whom they could recover that portion of the claim. ${ }^{64}$
}

Given that a concurrent defendant is at risk of being liable for damage caused or contributed to by other tortfeasors responsible for the same damage, it is in their interest to ensure that all liable tortfeasors are before the court and should take steps to join them where the plaintiff does not bring the claim against such persons. ${ }^{65}$

(2000), 51 OR (3d) 384 at paras 30-33, 48 (CA) [Martin].

Supra note 3. See also BC Negligence Act, supra note 2, s 1(3).

Supra note 59 at para 48.

Ibid.

In $M(J)$, Justice Cronk recognized the potential prejudice to non-parties when they do not have the opportunity to respond to claims against them but noted that was not the situation in the case at bar (supra note 32 at paras 45-46). See also Milne $v$ St Joseph's Health Centre (2009), 69 CCLT (3d) 208 (Ont Sup Ct J) [Milne].

Martin, supra note 59 at para 36.

See Ontario Negligence Act, supra note 3, s 5; Alberta Contributory Negligence Act, supra note 3, s 6; Saskatchewan Contributory Negligence Act, supra note 3, s 7; NB Contributory Negligence Act, supra note 18, s 6; Contributory Negligence Act, RSPEI 1988, c C-21, s 5; Contributory Negligence Act, RSNL 1990, c C-33, s 7; Contributory Negligence Act, RSNWT 1988, c C-18, s 7; Contributory Negligence Act, RSY 2002, c 42, s 6; British Columbia, Supreme Court Civil Rules, r 6-2(7); Manitoba, Court of Queen's Bench Rules, r 5.04(3); Misko, supra note 41 at para 15; Thompson v O'Sullivan, 2009 CanLII 15455 at para 29 (Ont Sup Ct J). A plaintiff has nothing to lose by not suing all concurrent 
In $M(J)$, the Ontario Court of Appeal clarified and distinguished Martin regarding the jurisdiction of a court to apportion fault and damages to non-parties. The Court emphasized the general jurisdiction of courts to apportion liability among concurrent tortfeasors in negligence cases, noting that this power can only be limited or abrogated by clear legislative intent, which is absent in section 1 of the Ontario Negligence Act. ${ }^{66}$ More importantly, the Court emphasized the concern of avoiding prejudice to non-parties, noting the different circumstances of the non-parties in Martin and the case at bar. In $M(J)$, the non-parties entered into a settlement agreement with the plaintiffs after they had initiated their action. The settlement included a term limiting the plaintiffs' action to the proportionate share of liability of the non-settling parties.

Like the doctors in Martin against whom the court made findings of fault and apportioned damages notwithstanding that they had settled with the plaintiff prior to the trial and were therefore not parties to the action, the settling defendants in $M(J)$ were not absent tortfeasors. Unlike the nurse in Martin, the settling defendants in both cases were named defendants in the plaintiffs' original statement of claim and they had an opportunity to defend the actions against them but chose to settle. The settling defendants are persons who would have been liable if sued. It was therefore appropriate for the court to apportion damages against them. However, this cannot be said of persons who were never sued, absent tortfeasors, including the nurse in Martin. ${ }^{67}$ The Court supported apportionment of damages to the non-parties in $M(J)$ because that would not prejudice any defendant by exposing them to liability caused or contributed to by the fault of absent tortfeasors. There were no absent tortfeasors in that case as the plaintiffs' action was against all tortfeasors and the settlement agreement, a Pierringer Agreement, ensured that the non-settling defendants were only liable for their proportionate share of liability for the plaintiffs' losses. In fact, the non-settling defendants did not object to apportioning fault to the settling defendants. ${ }^{68}$ Rather, it was in their interest to do so in order to determine the extent of their fault and hence liability to the plaintiff.

The Ontario Court of Appeal has subsequently cast doubt on the correctness of Martin. ${ }^{69}$ In Taylor v. Canada (Minister of Health), Justice Laskin reiterated Justice Rosenberg's comments in Misko that the alleged authority of Martin regarding apportionment of fault to non-parties was obiter and hence has no precedential value. ${ }^{70}$ Justice Laskin also observed that fault can be apportioned against non-parties in appropriate cases. In fact, courts have done so in subsequent cases and, in any event, section 1 of the Ontario Negligence Act directs courts to apportion fault among any persons whose fault or negligence caused or contributed to the plaintiff's damage and does not limit apportionment to the parties in the action. Thus, the Ontario Negligence Act gives courts the jurisdiction to apportion liability and hence

tortfeasors who have caused or contributed to their damage. As has been emphasized throughout this article, it is entirely within the plaintiff's right to sue any concurrent tortfeasor and recover her or his entire losses. Thus, it is in the defendant's best interest to ensure all tortfeasors are part of the main action to ensure proper determination of liability and apportionment of damages. This will eliminate difficulties in contribution and indemnity claims including challenges to findings of liability and apportionment or reasonableness of settlement amount. This is the approach recommended by the US National Conference of Commissioners on Uniform State Laws with the exception of parties that have been released by the plaintiff: Tort Responsibility Act, supra note 28, § 7(c)(1).

Ontario Negligence Act, supra note 3, s 13; $M(J)$, supra note 32 at paras 43-44.

$M(J)$, ibid at paras $45-52$.

Ibid at paras 53-59.

See Misko, supra note 41.

2009 ONCA 487, 95 OR (3d) 561 at paras 25-29 [Taylor]. 
damages against a person liable for the plaintiff's injuries but who is not a party to the main action brought by the injured person, and courts can exercise that discretion in appropriate situations. ${ }^{71}$ Further, Justice Laskin noted that there are practical advantages to the court's ability to apportion fault to non-parties such as avoiding complex trials, having shorter trials with fewer parties, and reducing costs. As well, it will encourage parties to settle in relation to certain issues. ${ }^{72}$ The court must be satisfied that there is sufficient evidential basis for apportioning fault for the plaintiff's loss against non-parties. ${ }^{73}$ Similarly, in Imperial Tobacco SC, the British Columbia Supreme Court affirmed that a trial court is entitled to determine the extent of fault of non-parties, including those who are immune from liability in the circumstances and could not have been sued in the first place. ${ }^{74}$

A finding of liability against and the apportionment of damages to non-parties is also mandated under certain statutory regimes that provide immunity to non-parties such as employers or employees in relation to injury or death of another worker in the course of employment. For instance, workers' compensation legislation specifically precludes actions against employers and employees for damages, contribution, or indemnity for losses caused by the negligence of an employer or worker. Yet courts are specifically directed to determine the extent of loss caused by that party's fault even though the plaintiff cannot recover those damages from the worker or employer and no contribution claim can be brought regarding that share of the plaintiff's damages. ${ }^{75}$

The above position supports a broader jurisdiction for courts to apportion fault among all tortfeasors, whether they are before the court or not. Such an approach facilitates the determination of the true extent of the fault of tortfeasors that are before the court. It also protects plaintiffs who may have settled for less than the settling tortfeasor's proportionate share of liability so long as the settlement did not limit any subsequent action to the nonsettling tortfeasor's share of the plaintiff's losses. This is consistent with the underlying rationale for joint liability to ensure full compensation for the plaintiff's losses. However, it may not be necessary, fair, or practical to apportion fault and damages to non-parties in all cases. A strict rule could undermine the goal of encouraging settlement.

71 This is consistent with the wording in apportionment legislation in other jurisdictions where courts are authorized to apportion fault (and hence damages), and also allow contribution and indemnity claims against persons not sued but, if sued, would have been liable for the plaintiff's losses: see Alberta Contributory Negligence Act, supra note 3, s 1; Tort-feasors Act, supra note 4, s 3(2); Saskatchewan Contributory Negligence Act, supra note 3, s 3(1), s 10; Nova Scotia Tortfeasors Act, supra note 4, s 3(c).

72 Taylor, supra note 70 at paras 23-29. See also Vardy $v$ Dufour et al, 2008 NLCA 22, 275 Nfld \& PEIR 247 at para 30 .

73 See Milne, supra note 63; Ryan Estate v Canada (Attorney General), 2015 NLTD(G) 90, 369 Nfld \& PEIR 122 at paras $28-36$.

Supra note 55 at para 90.

See Workers' Compensation Act, RSBC 1996, c 492, s 10(7) [BC Workers' Compensation Act]:

If, in an action brought by a worker or dependant of a worker or by the board, it is found that the injury, disablement or death, as the case may be, was due partly to a breach of duty of care of one or more employers or workers under this Part, no damages, contributions or indemnity are recoverable for the portion of the loss or damage caused by the negligence of that employer or worker; but the portion of the loss or damage caused by that negligence must be determined although the employer or worker is not a party to the action.

See also Workplace Safety and Insurance Act, SO 1997, c 16, Schedule A, s 29(3); Workers' Compensation Act, RSNB 1973, c W-13, s 10(12); Tort Responsibility Act, supra note 28, § 4 limits apportionment of fault only in relation to parties before the court and released persons. 
It follows that courts should have discretion to determine the liability of and apportion damages against non-parties even when the plaintiff's claim is limited to the proportionate share of his or her damage attributable to the fault of the named defendants, and hence there is no basis to seek contribution and indemnity. The discretion may be exercised where there is no potential for unfairness to non-parties, such as where findings of liability and apportionment of fault will not expose non-parties to liability because of statutory or other immunity. ${ }^{76}$ Courts may also exercise the discretion where the plaintiff's claim in the main action is specifically limited to the proportionate share of damages attributable to the fault of the defendants in that action and there is no possibility of a claim for contribution and indemnity from the non-parties. ${ }^{77}$ In such cases, it is important for the court to determine the liability and degree of fault attributable to all concurrent tortfeasors, including non-parties, in order to ascertain the proportionate share of damages of the defendants before the court. This is also necessary to ensure fairness between concurrent tortfeasors. ${ }^{78}$ However, the determinations of fault and apportionment of damages will not prejudice the interests of the non-parties nor would they bind them.

\section{CONCLUSION}

The common law position of joint liability of concurrent tortfeasors causing the same damage protects the interests of injured persons for full compensation while specifically prohibiting paying tortfeasors from seeking contribution from co-tortfeasors. The situation leaves the paying defendants to bear the entire risk of the plaintiff's loss while bestowing an undeserved benefit on concurrent tortfeasors, regardless of their ability to satisfy their share of the injured party's loss. Apportionment legislation has been adopted to remedy the rigidity of the common law. However, this is only a first step towards a just and fair approach to wrongs involving multiple tortfeasors liable for the same damage. This article has identified three areas where reforms are needed to ensure fairness between concurrent tortfeasors liable for the same damage. Firstly, provincial apportionment statutes need to follow Saskatchewan's example, and allow equitable contribution among joint tortfeasors when it is just. Secondly, courts need to resolve the conflict over proportionate share settlement agreements, giving clear guidelines on when, if ever, a settling tortfeasor will remain in an action by the injured party. Lastly, courts need to have a broad, discretionary power to attribute fault to non-parties. Each of these reforms would give clarity to the law, encourage settlement and efficiency, and mitigate the arbitrary nature of the current regime.

\footnotetext{
76 See e.g. Imperial Tobacco SC, supra note 55; BC Workers' Compensation Act, ibid, s 10(7).
}

77 See Taylor, supra note 70; M (J), supra note 32. It is worth noting that even in Martin, supra note 59 , the Ontario Court of Appeal accepted the trial judge's apportionment of liability and damages against two doctors originally named as defendants in the plaintiff's action but subsequently settled and therefore were not partied at trial.

78 See $M(J)$, ibid at paras 69-70; Amoco, supra note 32 at paras 69-70; BC Ferry, supra note 41 at paras 30-31; Murphy Canada Exploration, supra note 53 at para 34. 